\title{
Students Entrepreneurship Intention in Metropolitan and Indonesia Free Trade Zone: Is it Different?
}

\author{
Albrian Fiky Prakoso, Riza Yonisa Kurniawan, Yoyok Soesatyo \\ Universitas Negeri Surabaya, Jl Ketintang Surabaya Kampus Unesa, Indonesia \\ albrianprakoso@unesa.ac.id, rizakurniawan@unesa.ac.id,yoyoksoesatyo@unesa.ac.id
}

\begin{abstract}
This study aims to determine the Entrepreneurship Intention of students in Universitas Negeri Surabaya (Unesa) which is a metropolitan area and Riau Islands University (Unrika) in Indonesia Free Trade Zone. To distinguish Entrepreneurship Intention from students in this study using Theory of Planned Behavior (TPB). This type of research is quantitative exploratory research data analysis using Structural Equation Modeling (SEM) with the WarpPLS approach. Respondents in this study are Unesa and Unrika students, 6th-semester Economics or had taken entrepreneurship courses with a total of 142 students. There are similar intentions of Unrika entrepreneurship with Unesa. In Unrika, they were in the free trade zone area so they were more consumptive towards electronics because of their low price and reluctant to be entrepreneurs. In the free trade zone, if we want to sell an item outside the island, it will be charged by the government, and the price will be same like the price from the outside of free trade zone. Moreover, most of their parents are workers or civil servants and not entrepreneurs. The cause of Unesa students is reluctant to become entrepreneurs because most of them want to become civil servants based on the influence of the family environment which on average comes from the village and works as a civil servant. For Unrika, most of them are college workers, so their mindset before and when they are studying is as workers.
\end{abstract}

Keywords: Difference, Entrepreneurship Intention, Unesa, Unrika.

\section{Introduction}

Entrepreneurship learning can support government programs on people-based economic programs. The Chancellor of Syiah Kuala (Unsyiah) Darussalam University in Banda Aceh, Prof. Samsul Rizal in Putra (2015) said, in general, the percentage of entrepreneurs in Indonesia was only $1.65 \%$ of the total population. These percentages are far behind compared to Singapore, Malaysia, or Thailand, each of which has an entrepreneur level of 7\%,5\%, and 3\%. Data from the Ministry of Cooperatives and Small and Medium Enterprises shows, currently the number of entrepreneurs in Indonesia has only reached $1.65 \%$ or around 3.7 million. Whereas to become a developed country, the number of entrepreneurs must be more, at least $2 \%$ of the total population. "Indonesia's population is 252 million people, it requires 4.8 million entrepreneurs," said Deputy of Human Resources Development (HR) Ministry of Cooperatives and SMEs Prakoso BS in Julianto (2017). Entrepreneurship learning is a compulsory subject as part of a study program in Indonesia. However, most students who graduate from college do not want to become entrepreneurs. In contrast to the phenomenon of entrepreneurial learning that occurs in Riau Islands University (Unrika). The majority of Unrika students are workers who want to go to college. This college operates in the afternoon until the evening. While the morning is used to work first. Mindset students in Unesa want when they graduate to become Civil Servants (PNS) or become employees.

Entrepreneurship learning in Indonesia is also not in line with expectations as happened at Surabaya State University (Unesa) and Unrika. Most of the students at this college are from the same district. This is because they think if they become entrepreneurs, the income they earn is not fixed. All efforts have been given to students in Indonesia such as the Entrepreneurial Student Program (in Indonesia called PMW) and Entrepreneurship Student Creativity Program (in Indonesia called PKM-K). When the program has finished, the entrepreneurial activities carried out also stop. Only a few continue their entrepreneurship. Moreover, when they have graduated from college, they will again become workers in an agency and are reluctant to become entrepreneurs. This study aims to determine the Entrepreneurship Intention of students in Universitas Negeri Surabaya (Unesa) which is a metropolitan area and Riau Islands University (Unrika) in Indonesia Free Trade Zone. This research is important to do immediately considering that more and more scholars in Indonesia are unemployed. Many also after graduating from S1 they actually become online motorcycle taxi drivers even though Indonesian baccalaureate has the potential to become a successful entrepreneur. With this research, it can be seen the cause of the low intention of entrepreneurship in Unesa and Unrika students. Suggestions for improvement of the two universities are also the focus of this study. 


\section{Literature Review}

Theory of Planned Behavior (TPB) was introduced by Ajzen (1991). In TPB some more determines a person's intentions, namely Attitudes, Subjective Norms, and Perceptions of Behavior Control. Several previous studies on the theory of planned behavior and entrepreneurial intentions have been carried out. Ridha, Burhanuddin, \& Wahyu (2017) research young entrepreneurs in Indonesia in agriculture. As with Justo De Jorge-Moreno, Laborda, \& Triguero (2012) also examined the intention of entrepreneurship, but his research sought to influence the intention of entrepreneurial students after being given economic and business education programs. Whereas Solesvik, Westhead, \& Matlay (2014) not only explored student entrepreneurial intentions in Ukraine but explored cultural factors there and their relationship with the intention of student entrepreneurship. Research on entrepreneurial intentions has been carried out in various countries. In Spain, Justo De Jorge-Moreno et al. (2012) found that students' entrepreneurial intentions declined when they had long taken lectures and when they had more knowledge about business reality. However, students' entrepreneurial intentions increase when they choose jobs in the field of public administration. Politics, Ketikidis, Diamantidis, \& Lazuras (2016) successfully predict social and commercial entrepreneurial intentions. His findings say that tensions in mission focus seem to be present in the early shaped intentions of potential social entrepreneurs. Whereas in China, the results of research that say cultural and social dimensions only explain a small part of entrepreneurial intentions (Pruett, Shinnar, Toney, Llopis, \& Fox, 2009).

Arshad, Farooq, Sultana, \& Farooq (2016) conducted research on students in the largest tertiary institutions throughout South Asia. Culture in China is once again discussed because the changes can make perceptions and the entrepreneurial intentions vary (Sharma, 2018). The results of his study say that perceived entrepreneurial self-efficacy of male students has a greater effect on entrepreneurship, but the perceived social norms of female students have a greater influence on entrepreneurship. Differences in male and female academic entrepreneurial intentions are also different in perceptions of support from business and financial networks and in starting businesses (Fernández-Pérez, Esther Alonso-Galicia, del Mar Fuentes-Fuentes, \& Rodriguez-Ariza, 2014). Entrepreneurship has a positive impact on entrepreneurial intentions. On the other hand, the best antisense for students' entrepreneurial intentions is an attitude (Joensuu-Salo, Varamäki, \& Viljamaa, 2015). Whereas Buli \& Yesuf (2015) say that the most predictable variable from entrepreneurial intention is the personal attitude toward behavior and perceived behavioral control. Unlike the previous research, in Karimi's research, J. A. Biemans, Lans, Chizari, \& Mulder (2014) found gender differences did not affect perceived behavior control and student entrepreneurial intentions at 7 universities in Iran. In UAE, the work ethics of wasted time, leisure, and self-reliance positively predict entrepreneurial intention while the centrality of work is unrelated to entrepreneurial intentions (Tipu \& Ryan, 2016). In Bosnia, the intention of student entrepreneurship can be increased by increasing overall business surrounding and entrepreneurial education (Palalić, Ramadani, Đilović, Dizdarević, \& Ratten, 2017).

Unlike in Greece, entrepreneurial intentions deteriorate for 4 years while they study and faculty members have a low entrepreneurial education mentality (Piperopoulos, 2012). Entrepreneurship Education is an important element that influences entrepreneurial intentions of young women in India (Srivastava \& Misra, 2017). In India \& America studies have been found that says that both hostile and benevolent sexism are positively related to entrepreneurial intentions of both men and women (Stedham \& Wieland, 2017). Whereas in Africa, the regulatory environment has a positive and significant impact on feasibility and desirability, furthermore both feasibility and desirability affect positive intentions (Urban \& Kujinga, 2017). In Norway, Anne Støren (2014) examines graduates in Norway who have taken various education in the field of entrepreneurship. Although there are fewer graduates in the entrepreneurship field, they are interested in entrepreneurship. While at Midwestern University, creativity has a direct and positive effect on students' entrepreneurial intentions (Smith, Sardeshmukh, \& Combs, 2016). Baluku, Löser, Otto, \& Schummer (2018) examine entrepreneurial intentions in other variables. According to him the personal initiative and career orientation are very important as a mediation of entrepreneurial intentions. Bellò, Mattana, \& Loi (2018) argue that providing new education programs can foster entrepreneurial intentions. Ajzen's model of planned behavior has also been studied in 12 countries by Engle et al. (2010). He succeeded in predicting entrepreneurial intentions in each of the research countries. 
Although the results are the same as predicted by Ajzen, the elements of the contribution model are significantly different in each country, but social norms are a significant predictor of entrepreneurial intentions in each country. Ajzen's model of planned behavior may have been refined by means of measuring identification - in place of attitudes toward entrepreneurship (Jarvis, 2016). Oftedal, Iakovleva, \& Foss (2018) also examined entrepreneurial intentions in 5 countries. The findings show that the 2 dimensions of the university context influence the intention of student entrepreneurship both relatively and normatively. Slightly different, self-employment intentions at the Florida Gulf Coast University can be predicted by perceived feasibility and net desirability (Segal, Borgia, \& Schoenfeld, 2005). Comparison of entrepreneurial intentions in 2 countries has also been carried out by González-Serrano, Valantine, Hervás, Pérez-Campos, \& Moreno (2018). His results say that there are significant differences between Spanish and Lithuanian sports science students. Thus students are expected to have a better entrepreneurial mentality.

Lithuanian students have a perceived behavior control and professional attraction which has a higher influence on entrepreneurial intentions than Spanish students. Then in 22 Continental countries, it was found "perceived capacity"; "Entrepreneurial intention" which will, in fact, influence the "rate of potential entrepreneurship" (Teixeira, Casteleiro, Rodrigues, \& Guerra, 2018). From several phenomena and previous research on entrepreneurial intentions, the entrepreneurial character of students can be measured through the theory of planned behavior and entrepreneurial intentions. Both of these factors have different views on each student. Differences in student characteristics also depend on the environment. The fundamental difference with some previous studies is that this study compares the intention of student entrepreneurship in the theory of planned behavior in Indonesia, namely Unrika, which is located in the Free Trade Zone and Unesa in the Metropolitan city. By doing this research in Unrika and Unesa, we can find out what factors make the character of students lack entrepreneurial intentions.

Research Hypothesis: Some previous studies have formed the background of the formulation of the hypothesis. The research can be described in the framework of thinking as follows:

Fig 1: The Theory of Planned Behavior

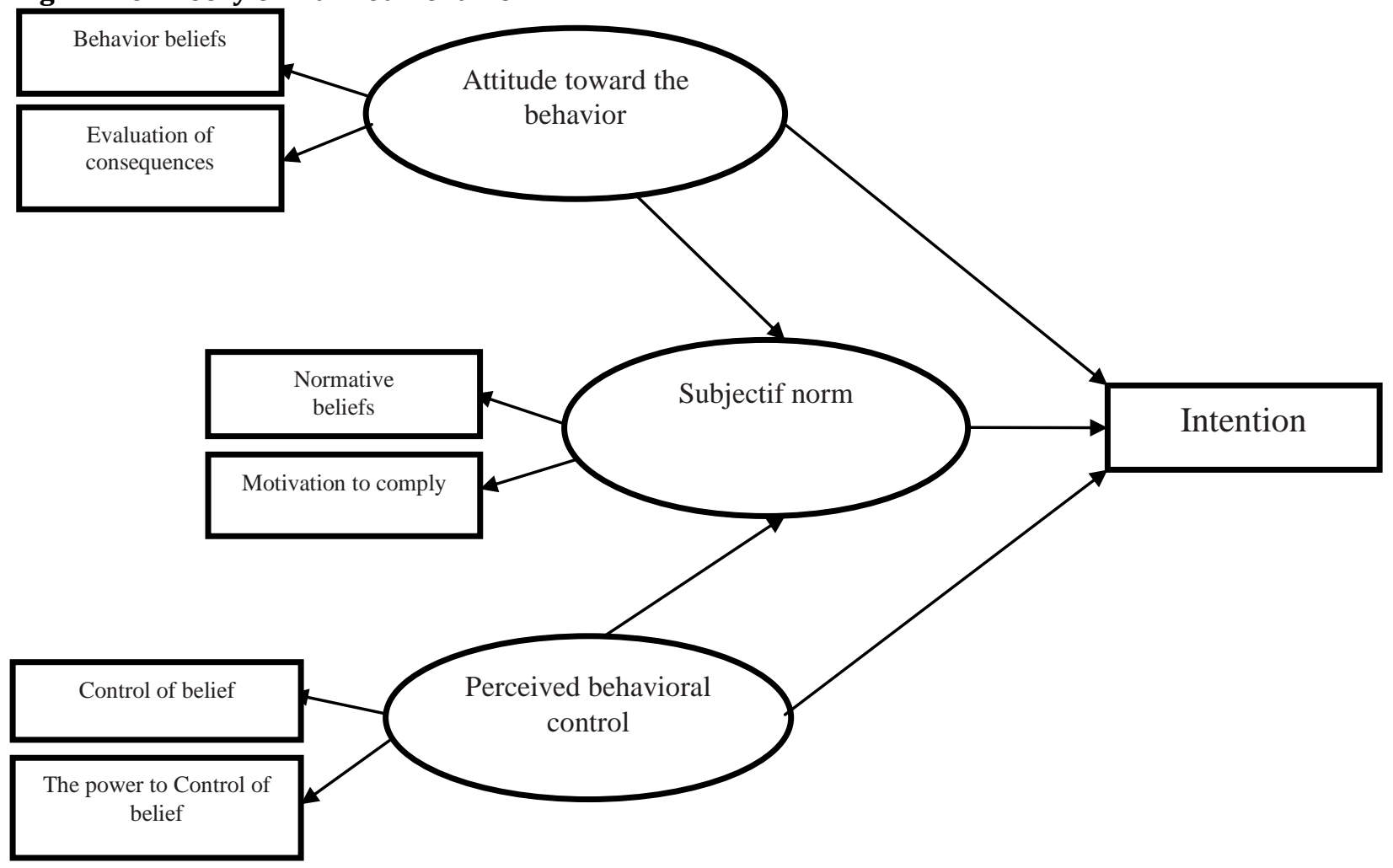

Source: Ajzen (1991) 
From the framework above, the research hypothesis is as follows:

H1: Is there any influence of Entrepreneurship Attitude on Unesa Student Entrepreneurial Intention?

H2: Is there any influence of Entrepreneurship Attitudes on the Intention of Unrika Student Entrepreneurs?

H3: Is there any influence of Subjective Norms on Unesa Student Entrepreneurial Intention?

H4: Is there any influence of Subjective Norms on the Intention of Unrika Student Entrepreneurs?

H5: Is there any influence of Perception of Behavioral Control on Unesa Student Entrepreneurial Intention?

H6: Is there any influence of Perception of Behavioral Control on the Intention of Unrika Student Entrepreneurs?

H7: Is there any influence of Entrepreneurship Attitude on the Subjective Norms of Unesa Student?

H8: Is there any influence of Entrepreneurship Attitude on the Subjective Norms of Unrika Student?

H9: Is there any influence of Perception of Behavioral Control on the Subjective Norms of Unesa Student?

H10: Is there any influence of Perception of Behavioral Control on the Subjective Norms of Unrika Student?

H11: Are Subjective Norms mediating influence of Entrepreneurship Attitude on the Intention of Unesa Student Entrepreneurs?

H12: Are Subjective Norms mediating influence of Entrepreneurship Attitude on the Intention of Unrika Student Entrepreneurs?

H13: Are Subjective Norms mediating influence of Perception of Behavioral Control on the Intention of Unesa Student Entrepreneurs?

H14: Are Subjective Norms mediating influence of Perception of Behavioral Control on the Intention of Unrika Student Entrepreneurs?

\section{Methodology}

The population used in this study were all students of the 6th semester of economic education study program at Unrika and Unesa with 142 students with details namely:

Table 1: Details of Research Population Data

\begin{tabular}{lll}
\hline No. & University & Total \\
\hline 1 & Unesa & 72 \\
2 & Unrika & 70 \\
Total & & 142 \\
\hline
\end{tabular}

Source: Unrika Administration and Unesa (2018)

Sampling techniques use saturated samples. According to Sugiyono (2017), saturated sampling is a sampling technique if all of the population are used as samples. So, all populations in this study were sampled. Although the number of samples is small for analysis of Structural Equation Models (SEM), which are generally a minimum of 200 but still can be done. This is because this research uses SEM with the method of the Warp Partial Least Square (WarpPLS) approach where this approach already contains a resampling method so that it can be done in a small number of samples. The minimum requirement for conducting SEM WarpPLS analysis is 30 (Solimun, Fernandes, \& Nurjannah, 2017). This research is a type of quantitative explorative research. Quantitative because data is a number. While including explorative because it aims to explore what factors influence the interests and intentions of student entrepreneurship. This research was conducted at the Economic Education Study Program at Unrika and Unesa. The study was conducted from March to October 2018.

Fig 2: Chart of Research Flow

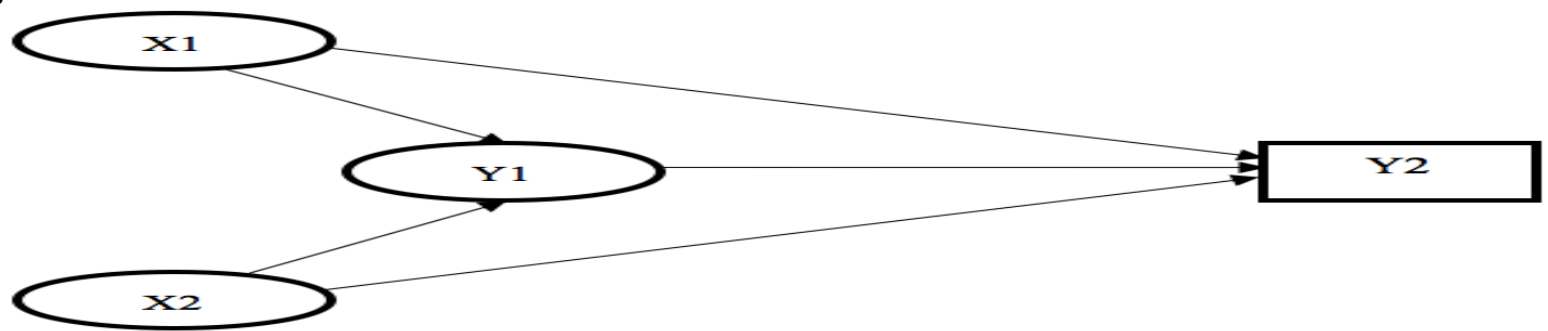

Source: Adoption of Ridha, Burhanuddin, and Wahyu (2017) 
Information: X1: Attitude toward the behavior Y1: Subjective Norms
X2: Perceived behavioral control

Y2: Intention

The test used is administering a questionnaire with a Likert scale in the form of a checklist with various indicators of Perception of Behavior Control, Subjective Norms, Perception of Behavior Control and Entrepreneurial Intention. In the Likert scale, there are 5 alternative answer choices consisting of Strongly Agree (SS), Agree (S), Neutral (N), Disagree (TS), Strongly Disagree (STS). This research also provides solutions to Unrika and Unesa so that entrepreneurship learning will be better. In collecting data, researchers used a Likert scale in the form of a closed statement aimed at 6th-semester students at Unesa and Unrika universities. According to Arikunto (2010), a good research instrument must fulfill two important requirements, namely valid and reliable. Data analysis in this study used the Structural Equation Model (SEM) method of the Warp Partial Least Square (WarpPLS) approach. Partial Least Square (PLS) is part of the WarpPLS. This analysis does not require data that are normally distributed and can be used in a small number of samples. PLS is used to predict constructs in models that contain several factors and have collinear relationships. One of the software used in this study is WarpPLS. The variables in this study only contain 4 exogenous latent variables with indicators that have ordinal data. The purpose of using PLS is to conduct confirmatory factor analysis. This is done because this study only aims to find out which indicators have the highest contribution in each research variable both in Unesa and Unrika. So there is no need to do the overall structural model.

\section{Results}

In the WarpPLS analysis, there are several sizes of the Fit Model and Quality Indices will be explained as follows:

Table 2: Fit and Quality Indices Models

\begin{tabular}{|c|c|c|c|c|c|c|}
\hline No & $\begin{array}{l}\text { Model Fit } \\
\text { and Quality } \\
\text { Indices }\end{array}$ & Fit Criteria & $\begin{array}{l}\text { Unesa } \\
\text { Result }\end{array}$ & Information & $\begin{array}{l}\text { Unrika } \\
\text { Result }\end{array}$ & Information \\
\hline 1 & APC & $\mathrm{p}<0,05$ & $\begin{array}{l}0,211 \\
(P=0,014)\end{array}$ & Good & $\begin{array}{l}0,159 \\
(\mathrm{P}=0.041)\end{array}$ & Good \\
\hline 2 & ARS & $\mathrm{p}<0,05$ & $\begin{array}{l}0,142 \\
(\mathrm{P}=0,052)\end{array}$ & $\begin{array}{l}\text { Good } \\
\text { enough }\end{array}$ & $\begin{array}{l}0,065 \\
(\mathrm{P}=0,144)\end{array}$ & Good enough \\
\hline 3 & AARS & $\mathrm{p}<0,05$ & $\begin{array}{l}0,105 \\
(P=0,089)\end{array}$ & $\begin{array}{l}\text { Good } \\
\text { enough }\end{array}$ & $\begin{array}{l}(0,023 \\
(\mathrm{P}=0,211)\end{array}$ & Good enough \\
\hline 4 & AVIF & $\begin{array}{l}\text { acceptable if }<=5, \\
\text { ideally }<=3.3\end{array}$ & 1,018 & Ideal & 1,043 & Ideal \\
\hline 5 & AFVIF & $\begin{array}{l}\text { acceptable if }<=5 \text {, } \\
\text { ideally }<=3.3\end{array}$ & 1,104 & Ideal & 1,242 & Ideal \\
\hline 6 & GoF & $\begin{array}{lrr}\text { small }>= & 0.1, \\
\text { medium }>= & 0.25, \\
\text { large }>=0.36 & \end{array}$ & 0,303 & Ideal & 0,222 & Ideal \\
\hline 7 & SPR & $\begin{array}{l}\text { acceptable if }>=0.7 \text {, } \\
\text { ideally }=1\end{array}$ & 0,7 & Ideal & 0,7 & Ideal \\
\hline 8 & RSCR & $\begin{array}{l}\text { acceptable if }>=0.9 \text {, } \\
\text { ideally }=1\end{array}$ & 0,940 & Ideal & 0,860 & Ideal \\
\hline 9 & SSR & acceptable if $>=0.7$ & 1,000 & Ideal & 1,000 & Ideal \\
\hline 10 & NLBCDR & acceptable if $>=0.7$ & 1,000 & Ideal & 0,7 & Ideal \\
\hline
\end{tabular}

When there is Chi-Square sensitive to the number of samples taken, it can be seen through the other Goodness of Fit criteria with $\mathrm{i} \geq 90$ (Ghozali, 2014). That is, from the results of the fittest of the AVIF model, AFVIF when acceptable if $=5$ and ideal $=3.3$ with the analysis results of 65,490 and 105,960 is considered ideal because it is still included in the Goodness of Fit criteria if $\geq 90$. The information conveyed on the variable profile is a combination of the identification of important indicators based on the factor load value (loading factor) with variable empirical conditions based on the average score. 
Table 3: Profile of Unesa Variables X1, X2, Y1, and Y2

\begin{tabular}{lllll}
\hline No & Indicator & Factor Loading & Mean Score & Suggestion \\
\hline 1 & $\begin{array}{l}\text { Behavior beliefs } \\
\text { (X1.1) }\end{array}$ & 0,946 & 4,4 & Maintained \\
2 & $\begin{array}{l}\text { Evaluation } \\
\text { consequences } \\
(X 1.2)\end{array}$ & 4,3 & Maintained \\
3 & $\begin{array}{l}\text { Normative beliefs } \\
\text { (Y1.1) }\end{array}$ & 0,927 & 3,2 & Improved \\
4 & $\begin{array}{l}\text { Motivation to comply } \\
\text { (Y1.2) }\end{array}$ & 0,938 & 4,3 & Maintained \\
5 & $\begin{array}{l}\text { Control belief } \\
(X 2.1)\end{array}$ & 0,952 & 4,1 & Maintained \\
6 & $\begin{array}{l}\text { Control belief power } \\
(X 2.2)\end{array}$ & 0,982 & 4,3 & Maintained \\
7 & $\begin{array}{l}\text { (Y2.1) } \\
(Y 2.2)\end{array}$ & 0,963 & 4,2 & Maintained \\
8 & 0,986 & 4 & Maintained \\
\hline
\end{tabular}

Table 4: Variable Profile X1, X2, Y1 and Y2 Unrika

\begin{tabular}{|c|c|c|c|c|}
\hline No & Indicator & Factor Loading & Mean Score & Suggestion \\
\hline 1 & $\begin{array}{l}\text { Behavior beliefs } \\
\text { (X1.1) }\end{array}$ & 0,915 & 4,6 & Maintained \\
\hline 2 & $\begin{array}{l}\text { Evaluation } \\
\text { consequences } \\
\text { (X1.2) }\end{array}$ & 0,854 & 4,4 & Maintained \\
\hline 3 & $\begin{array}{l}\text { Normative beliefs } \\
\text { (Y1.1) }\end{array}$ & 0,840 & 3,1 & Improved \\
\hline 4 & $\begin{array}{l}\text { Motivation to comply } \\
\text { (Y1.2) }\end{array}$ & 0,808 & 4,4 & Maintained \\
\hline 5 & $\begin{array}{l}\text { Control of belief } \\
\text { (X2.1) }\end{array}$ & 0,852 & 4,3 & Maintained \\
\hline 6 & $\begin{array}{l}\text { The power to Control of } \\
\text { belief } \\
\text { (X2.2) }\end{array}$ & 0,901 & 4,5 & Maintained \\
\hline 7 & $(Y 2.1)$ & 0,967 & 2,7 & $\begin{array}{l}\text { Enhanced } \\
\text { immediately }\end{array}$ \\
\hline 8 & (Y2.2) & 0,989 & 2,4 & $\begin{array}{l}\text { Enhanced } \\
\text { immediately }\end{array}$ \\
\hline
\end{tabular}

When the load factor (loading factor) gets bigger. indicates that indicators are increasingly strong reflecting or becoming important indicators in these variables. Of several variables. important indicators are:

a) The variable X1 with an important indicator in Unesa is X1.1 with a factor load of 0.946 for X1.1 with a factor load of 0.915 with good conditions to maintain.

b) The variable Y1 with an important indicator in Unesa is Y1.2 with a factor load of 0.938 . While Unrika Y1.1 with a factor load of 0.840 , with good conditions to be maintained at Unesa, Whereas Unrika must be increased.

c) The variable X2 with an important indicator in Unesa is X2.2 with a factor load of 0.982 whereas Unrika X2.2 with a factor loads of 0.982 , with good conditions to maintain.

d) The variable Y2 with an important indicator in Unesa is Y2.2 with a factor load of 0.946 . While Unrika Y2.2 with a factor loads of 0.989 the advice for Unesa is to defend it. Unrika must be upgraded immediately. 
Table 5: Unesa's and Unrika's Path Coefficient and P-Values of Direct Effect

\begin{tabular}{|c|c|c|c|c|c|c|}
\hline \multirow{2}{*}{ No. } & \multicolumn{2}{|c|}{$\begin{array}{l}\text { Relationship Between Variables } \\
\text { Variable } \rightarrow \text { Endogenous Variable) }\end{array}$} & \multirow{2}{*}{$\begin{array}{l}\text { Unesa } \\
\text { Path } \\
\text { Coefficient }\end{array}$} & \multirow[b]{2}{*}{ P-Value } & \multirow{2}{*}{$\begin{array}{l}\text { Unrika } \\
\text { Path } \\
\text { Coefficient } \\
\end{array}$} & \multirow[b]{2}{*}{ P-Value } \\
\hline & Exogenous Variable & Endogenous Variable & & & & \\
\hline 1 & $\begin{array}{l}\text { Attitude toward the } \\
\text { behavior }\end{array}$ & Intention & 0.078 & 0.246 & -0.102 & 0.189 \\
\hline 2 & Subjectif norm & Intention & -0.330 & 0.001 & 0,141 & 0,110 \\
\hline 3 & $\begin{array}{l}\text { Perceived behavioral } \\
\text { control }\end{array}$ & Intention & 0.224 & 0.021 & 0,233 & 0,019 \\
\hline 4 & $\begin{array}{l}\text { Attitude toward the } \\
\text { behavior }\end{array}$ & Subjectif norm & 0.413 & $<0.001$ & 0.469 & $<0.001$ \\
\hline 5 & $\begin{array}{l}\text { Perceived behavioral } \\
\text { control }\end{array}$ & Subjectif norm & -0.201 & 0.035 & 0.377 & $<0.001$ \\
\hline
\end{tabular}

a. Effect of Student Attitudes (X1) on Entrepreneurial Intention (Y2) of Unesa with path coefficients of 0.078 and $p=0.246$. Given that $p$ is greater than 0.10 (significant level of $p$-value $10 \%$ ) it is said to be insignificant, so the hypothesis is rejected.

b. Effect of Subjective Norms (Y1) on Entrepreneurial Intention (Y2) of Unesa with path coefficients of -0.330 and $p=0.001$. Given that $p$ is smaller than 0.01 (significant level of $p$-value $1 \%$ ), it is said to be highly significant and negative, so that the hypothesis is accepted.

c. Effect of Perceived behavioral control (X2) on Entrepreneurial Intention (Y2) of Unesa with a path coefficient of 0.224 and $p=0.021$. Given that $p$ is less than 0.05 (significant level of $p$-value $5 \%$ ), it is said to be positively significant, so that the hypothesis is accepted.

d. Effect of Student Attitudes (X1) on Entrepreneurial Intention (Y2) of Unrika with path coefficients of -0.102 and $p=0.189$. Given that $p$ is greater than 0.05 (significant level of $p$-value $5 \%$ ), it is said to be insignificant, so the hypothesis is rejected.

e. Effect of Subjective Norms (Y1) on Entrepreneurial Intention (Y2) of Unrika with path coefficients of 0.141 and $p=0.110$. Given that $p$ is greater than 0.10 (significant level of $p$-value $10 \%$ ) it is said to be insignificant, so the hypothesis is rejected.

f. Effect of Perceived behavioral control (X2) on Entrepreneurial Intention (Y2) of Unrika with path coefficients of 0.233 and $p=0.019$. Given that $p$ is less than 0.05 (significant level of $p$-value $5 \%$ ), it is said to be positively significant, so that the hypothesis is accepted.

g. Effect of Attitude toward the behavior (X1) on Subjective Norms (Y1) of Unesa with path coefficients 0.413 and $\mathrm{p}<0.001$. Given that $\mathrm{p}$ is smaller than 0.01 (significant level of $\mathrm{p}$-value $1 \%$ ), it is said to be highly significant and positive, so that the hypothesis is accepted.

h. Effect of Attitude toward the behavior (X1) on Subjective Norms (Y1) of Unrika with path coefficients 0.469 and $p<0.001$. Given that $p$ is smaller than 0.01 (significant level of $p$-value $1 \%$ ), it is said to be highly significant and positive, so that the hypothesis is accepted.

i. Effect of Perceived behavioral control (X2) on Subjective Norms (Y1) of Unesa with path coefficients -0.201 and $p=0.035$. Given that $p$ is smaller than 0.05 (significant level of $p$-value $5 \%$ ), it is said to be significantly negative, so that the hypothesis is accepted.

j. Effect of Perceived behavioral control (X2) on Subjective Norms (Y1) of Unrika with path coefficients 0.377 and $\mathrm{p}<0.001$. Given that $\mathrm{p}$ is smaller than 0.01 (significant level of $\mathrm{p}$-value $1 \%$ ), it is said to be highly significant and positive, so that the hypothesis is accepted.

Table 6: Unesa's and Unrika's Path Coefficient and P-Values of Indirect Effect

\begin{tabular}{|c|c|c|c|c|c|c|c|}
\hline \multirow{2}{*}{ No. } & \multicolumn{5}{|c|}{$\begin{array}{l}\text { Relationship Between Variables (Exogeno } \\
\text { Variable } \rightarrow \text { Endogenous Variable) }\end{array}$} & \\
\hline & $\begin{array}{l}\text { Exogenous } \\
\text { Variable }\end{array}$ & $\begin{array}{l}\text { Moderating } \\
\text { Variable }\end{array}$ & $\begin{array}{l}\text { Endogenous } \\
\text { Variable }\end{array}$ & $\begin{array}{l}\text { Path } \\
\text { Coefficient }\end{array}$ & P-Value & $\begin{array}{l}\text { Path } \\
\text { Coefficient }\end{array}$ & P-Value \\
\hline 1 & $\begin{array}{l}\text { Attitude } \\
\text { toward the } \\
\text { behavior (X1) }\end{array}$ & $\begin{array}{l}\text { Subjective } \\
\text { Norms (X2) }\end{array}$ & $\begin{array}{l}\text { Entrepreneurial } \\
\text { Intention }(\mathrm{Y})\end{array}$ & $-0,136$ & 0.044 & 0.066 & 0.212 \\
\hline
\end{tabular}




\begin{tabular}{|c|c|c|c|c|c|c|c|}
\hline 2 & $\begin{array}{l}\text { Perceived } \\
\text { behavioral } \\
\text { control (X3) }\end{array}$ & $\begin{array}{l}\text { Subjective } \\
\text { Norms (X2) }\end{array}$ & $\begin{array}{l}\text { Entrepreneurial } \\
\text { Intention }(\mathrm{Y})\end{array}$ & 0.066 & 0.206 & 0.053 & 0.261 \\
\hline
\end{tabular}

a) Subjective Norms (Y1) mediating influence of Entrepreneurship Attitude (X1) on the Intention of Unesa Student Entrepreneurs (Y2) with path coefficients -0.136 and $p=0.044$. Given that $p$ is smaller than 0.05 (significant level of p-value $5 \%$ ), it is said to be significant and negative, so that the hypothesis is accepted.

b) Subjective Norms (Y1) mediating influence of Entrepreneurship Attitude (X1) on the Intention of Unrika Student Entrepreneurs (Y2) with path coefficients 0.066 and $p=0.212$. Given that $p$ is greater than 0.1 (significant level of p-value 10\%), it is said to be insignificant, so that the hypothesis is rejected.

c) Subjective Norms (Y1) mediating influence of Perception of Behavioral Control (X2) on the Intention of Unesa Student Entrepreneurs (Y2) with path coefficients 0.066 and $p=0.206$. Given that $\mathrm{p}$ is greater than 0.1 (significant level of p-value 10\%), it is said to be insignificant, so that the hypothesis is rejected.

d) Subjective Norms (Y1) mediating influence of Perception of Behavioral Control (X2) on the Intention of Unesa Student Entrepreneurs (Y2) with path coefficients 0.053 and $p=0.261$. Given that $\mathrm{p}$ is greater than 0.1 (significant level of p-value 10\%), it is said to be insignificant, so that the hypothesis is rejected.

\section{Discussion}

The attitude of Unesa students does not have an influence on student entrepreneurial intentions. This is the same as the results of research conducted by Ridha et al. (2017). Unesa students have fairly good behavior with proven time respect such as collecting lectures on time or completing them before a predetermined time limit. Dare to bear the risk of all activities carried out. Have integrity, proven by working on assignments and exams honestly and confidently. Creative and innovative in giving opinions in lectures. Independence is also reflected when they are asked to learn new material. When studying in groups, leadership spirit is also seen in them during discussion activities. Diligent and disciplined look at the way they do the assignments given. While the evaluation of the consequences of Unesa students is lower than behavioral beliefs, but the difference is not far adrift. Unesa students assess that respecting time, taking risks, integrity, confidence, creative, innovative, independent, the spirit of leadership, diligence and discipline are important things. The empirical conditions of behavioral beliefs and the evaluation of the consequences of Unesa students both have high scores but this has no effect in increasing entrepreneurial intentions. Same with Unesa, the attitude of Unrika students also does not affect the intention of student entrepreneurship. Even though they have an attitude of respect for time, risk, integrity, confidence, creative, innovative, independent, the spirit of leadership, perseverance, and discipline, this attitude is reflected in their activities at work. This is because most Unrika students are college employees. Thus the advice that can be given to Unesa and Unrika is to provide knowledge and convince them that the attitude they have can be applied when they are selfemployed. Because by having an entrepreneurial attitude, they can appreciate the time. Then when they do business, they dare to bear the risk if there is a failure and face many obstacles.

They can apply the integrity attitude of students when they are self-employed by upholding honesty. The making of the products they want to make is strongly supported by having an attitude of confidence, creativity, innovation so that their products have their own characteristics compared to other products. With entrepreneurship, they can also be independent in the sense that they can have their own income regardless of the gift of parents. If they become employees, they are subordinates, but if they become entrepreneurs, they are bosses who certainly have the leadership spirit to manage their employees. When starting a business from zero the diligent attitude and discipline they have is very necessary. If this attitude is not owned, the business they are initiating will fail. Data collection techniques in the form of unstructured interviews and questionnaires with closing statements. Based on the research results of Rifkhan (2017) that attitudes, motivations, and interests in entrepreneurship have a high influence to foster interest in entrepreneurship. Whereas Andika \& Madjid (2012) stated that attitudinal variables, subjective norms, and simultaneous selfefficacy significantly influence entrepreneurial intention in Unsyiah Economics Faculty students. The results 
of this hypothesis test same as the results of research conducted by of Andika \& Madjid (2012), Ditya \& Waspada (2011), Karali (2013), and Suharti \& Sirine (2011). Subjective Norms for Unesa's Intention are very significant but negative. The influence is the biggest of the Unrika students. This is because the support from Unesa is very high. Indicators of normative beliefs embodied in the possession of a business incubator unit at the University function to accommodate student business pilot project. Unesa also has an Entrepreneurship Development and Management Center Team whose job is to accommodate student business pilot project in the Faculty of Economics.

Unesa also provides PMW services that foster and provide business capital assistance competed. Finally, Unesa also provides clinics when students make PKM-K. Apart from lecturers and universities, parents and friends also received support from Unesa students. However, the higher the support from lecturers, universities, parents and friends, the more reluctant Unesa students will become entrepreneurs. It should be noted that students who are respondents in Unesa are students of economic education study programs, where they are directed to become economics teachers. After analysis, information was obtained that their passion was indeed being a teacher. Most Unesa students have different expectations from those around them. Motivation indicators to fulfill in the form of expectations of lecturers, universities, parents, and friends want them to be able to become entrepreneurs, but they want to become teachers. They prefer teaching rather than entrepreneurship. Subjective Norms owned by Unrika students have no effect on entrepreneurial intentions. Based on the analysis carried out, most Unrika students are employees. Indicators of normative beliefs are manifested in the support given by entrepreneurship seminars, entrepreneurial events, and entrepreneurial talk shows. The efforts that have been made have not been able to convince Unrika students of their entrepreneurial intentions. While the motivation indicators to meet the expectations of lecturers, organizations, parents, and friends, want them to become entrepreneurs. But their hopes are different. Because most of the students are employees, the time at work is more than the time for college.

Suggestions that can be given to Unesa is to reduce the intensity of Subjective Norms because it will reduce their student's Entrepreneurial Intentions. While the advice given to Unrika is not to focus too much or even not need to improve or improve the subjective norms of students because it will not have an impact on the student's entrepreneurial intentions. Then Unrika is advised to analyze other factors besides subjective norms which have an impact on increasing student entrepreneurial intentions. Wijaya (2009) research results state that entrepreneurial attitudes, subjective norms, and self-efficacy have an influence on entrepreneurial behavior through intention. While Sarwoko (2011) shows that entrepreneurial intentions are influenced by subjective norms and self-efficacy, where the effect is positive, the higher the support for students, the higher the intention to become entrepreneurs, as well as the higher self-esteem and mental maturity, the higher the intention entrepreneurship. The results of this hypothesis test same as the results of research conducted by of Karali (2013), Sarwoko (2011), Tong, Tong, \& Loy (2011), as well as different findings from the Andika \& Madjid (2012) study. Perception of Behavior Control possessed by Unesa and Unrika students have a positive and significant impact on Entrepreneurial Intention. Thus any amount of normative beliefs and their motivation does not have any impact on the Unrika student entrepreneurial intention. This is because Unesa and Unrika come from Indonesia. In Indonesia, accessing financial institutions is easily accessible to students. Such access can be in the form of online access or direct visits to the institution. Unesa and Unrika students also have similarities namely they feel easy in overcoming fatigue/boredom, especially in lecture activities.

When faced with the problem of entrepreneurial difficulties, both Unesa and Unrika students find it difficult. This is certainly a very good capital because it can be applied to entrepreneurship such as failure or the products they sell are not selling well, they will quickly find a solution. On the other hand, Unesa and Unrika students are equally trustworthy in fulfilling the agreement. This can be applied when they collaborate with other institutions so that the collaboration can run successfully because they hold the mandate. Thus the advice that can be given to Unesa and Unrika is to maintain the Behavioral Control Perception of their students. The results of the research by Suharti \& Sirine (2011) show the significance of attitudinal factors in influencing the interests of student entrepreneurship. Furthermore, this study also proves the important role of contextual factors, such as academic support, social support, and the intention of entrepreneurship among students. The results of this hypothesis test same as the results of research conducted by of Andika \& Madjid (2012), Azizah (2017), Kurniawan (2011), and Sarwoko (2011). From all the results of the discussion, it was 
found that in Unrika, they were in the free trade zone area so they were more consumptive towards electronics because of their low price and reluctant to be entrepreneurs because, Unesa is in an environment with the same lifestyle as developed countries where the purpose of consumption is prestige rather than just meeting needs. To do entrepreneurship is still controlled by capital owners (general importers) and usually they are also descendants of entrepreneurship as well. In the free trade zone, if we want to sell an item outside the island, it will be charged by the government, and the price will be same like the price from the outside of free trade zone.

\section{Conclusion and Recommendations}

Based on the results of the study it can be concluded that the attitude of Unesa students influences the intention of student entrepreneurship. Actually, Unesa students have fairly good behavioral beliefs, as evidenced by their respect for time, such as collecting lectures on time or completing them before the lecturer has set a deadline. Moreover, most of their parents are workers or civil servants and not entrepreneurs. This also influences them to become individuals who rely on income from parents and then use it for consumption rather than being used for entrepreneurship because, Unesa is in an environment with the same lifestyle as developed countries where the purpose of consumption is prestige rather than just meeting needs. The advice that can be given from this research for Unesa is to maintain the behavioral beliefs of its students. Subjective Norms for Unesa's Intention are very significant but negative. The influence is the biggest instead of the Unrika students. This is because the support from Unesa is very high. Indicators of normative beliefs embodied in the possession of a business incubator unit at the University level are the function of accommodating the pilot project business of the Students. Perceptions of Behavior Control possessed by Unesa and Unrika students both have a positive and significant impact on Entrepreneurial Intention. This is because Unesa and Unrika are from Indonesia. Suggestions that can be given for unesa is precisely in order to reduce activities related to Subjective Norms. Whereas the suggestion for Unrika and Unesa is to improve Perceptions of Behavior Control in the form of various support activities related to entrepreneurial learning. Based on the conclusions above, each campus needs to improve activities related to entrepreneurial practice in order to foster entrepreneurial intentions and also to increase creativity in developing student talents in the field of entrepreneurship.

\section{References}

Ajzen, I. (1991). The Theory of Planned Behavior. Organizational Behavior and Human Decision Processes, 50. Andika, M. \& Madjid, I. (2012). Analisis Pengaruh Sikap, Norma Subyektif dan Efikasi Diri Terhadap Intensi Berwirausaha Pada mahasiswa Fakultas Ekonomi Universitas Syiah Kuala. In Eco-Entrepreneurship Seminar \& Call for Paper" Improving Performance by Improving Environment, 190-196.

Anne Støren, L. (2014). Entrepreneurship in higher education. Education + Training, 56(8/9), 795-813.

Arikunto, S. (2010). Prosedur Penelitian : Suatu Pendekatan Praktik (Edisi Revisi). Jakarta: Rineka Cipta.

Arshad, M., Farooq, O., Sultana, N. \& Farooq, M. (2016). Determinants of individuals' entrepreneurial intentions: a gender-comparative study. Career Development International, 21(4), 318-339.

Azizah, N. (2017). Efektifitas Pendidikan Kewirausahaan dan Self Efficacy Terhadap Minat Berwirausaha. AlMu'amalat, 2(II), 427-446.

Baluku, M. M., Löser, D., Otto, K. \& Schummer, S. E. (2018). Career mobility in young professionals. Journal of Global Mobility: The Home of Expatriate Management Research, 6(1), 102-122.

Bellò, B., Mattana, V. \& Loi, M. (2018). The power of peers: A new look at the impact of creativity, social context and self-efficacy on entrepreneurial intentions. International Journal of Entrepreneurial Behavior \& Research, 24(1), 214-233.

Buli, B. M. \& Yesuf, W. M. (2015). Determinants of entrepreneurial intentions. Education + Training, 57(8/9), 891-907.

Ditya, G. \& Waspada, I. (2011). Faktor-faktor yang Mempengaruhi Minat Berwirausaha Mahasiswa Universitas Pendidikan Indonesia. Portal Jurnal, 6(1).

Engle, R. L., Dimitriadi, N., Gavidia, J. V., Schlaegel, C., Delanoe, S., Alvarado, I. \& Wolff, B. (2010). Entrepreneurial intent: A twelve-country evaluation of Ajzen's model of planned behavior. International Journal of Entrepreneurial Behavior \& Research, 16(1), 35-57. 
Fernández-Pérez, V., Esther Alonso-Galicia, P., del Mar Fuentes-Fuentes, M. \& Rodriguez-Ariza, L. (2014). Business social networks and academics' entrepreneurial intentions. Industrial Management \& Data Systems, 114(2), 292-320.

Ghozali, I. (2014). Model Persamaan Struktural Konsep dan Aplikasi Dengan Program AMOS 22.0 Update Bayesian SEM (6th ed.). Semarang: Universitas Diponegoro.

González-Serrano, M. H., Valantine, I., Hervás, J. C., Pérez-Campos, C. \& Moreno, F. C. (2018). Sports university education and entrepreneurial intentions. Education + Training, 60(5), 389-405.

Jarvis, L. C. (2016). Identification, intentions and entrepreneurial opportunities: an integrative process model. International Journal of Entrepreneurial Behavior \& Research, 22(2), 182-198.

Joensuu-Salo, S., Varamäki, E. \& Viljamaa, A. (2015). Beyond intentions - what makes a student start a firm? Education + Training, 57(8/9), 853-873.

Julianto, P. A. (2017). Pemerintah Terus Motivasi Pemuda untuk Jadi Wirausahawan.

Justo De Jorge-Moreno, Laborda, L. \& Triguero, M. S. (2012). The effect of business and economics education programs on students' entrepreneurial intention. European Journal of Training and Development, 36(4), 409-425.

Karali, S. (2013). The Impact of Entrepreneurship Education Program on Entrepreneurial Intention: An Application of The Theory of Planned Behavior. Unpublished Master's Thesis.

Karimi, S. J. A., Biemans, H., Lans, T., Chizari, M. \& Mulder, M. (2014). Effects of role models and gender on students' entrepreneurial intentions. European Journal of Training and Development, 38(8), 694-727.

Kurniawan, T. D. (2011). Intensi berwiraisaha siswa sekolah menengah kejuan (SMK) Negeri 22 Jakarta: peran self efficacy, loc, risk taking behavior, eq, dan aq.

Oftedal, E. M., Iakovleva, T. A. \& Foss, L. (2018). University context matter. Education + Training, 60(7/8), 873-890.

Palalić, R., Ramadani, V., Đilović, A., Dizdarević, A. \& Ratten, V. (2017). Entrepreneurial intentions of university students: a case-based study. Journal of Enterprising Communities: People and Places in the Global Economy, 11(3), 393-413.

Piperopoulos, P. (2012). Could higher education programmes, culture and structure stifle the entrepreneurial intentions of students? Journal of Small Business and Enterprise Development, 19(3), 461-483.

Politis, K., Ketikidis, P., Diamantidis, A. D. \& Lazuras, L. (2016). An investigation of social entrepreneurial intentions formation among South-East European postgraduate students. Journal of Small Business and Enterprise Development, 23(4), 1120-1141.

Pruett, M., Shinnar, R., Toney, B., Llopis, F. \& Fox, J. (2009). Explaining entrepreneurial intentions of university students: a cross-cultural study. International Journal of Entrepreneurial Behavior \& Research, 15(6), 571-594.

Putra, E. P. (2015). Rektor: Pengusaha di Indonesia 1, 65 Persen, Singapura 7 Persen Penduduk.

Ridha, R. N., Burhanuddin. \& Wahyu, B. P. (2017). Entrepreneurship intention in agricultural sector of young generation in Indonesia. Asia Pacific Journal of Innovation and Entrepreneurship, 11(1), 76-89.

Rifkhan, R. (2017). Pengaruh Sikap, dan Motivasi terhadap Minat Berwirausaha Mahasiswa Akuntansi Universitas Pamulang. Jurnal Ilmiah Akuntansi Universitas Pamulang, 5(1).

Sarwoko, E. (2011). Kajian empiris entrepreneur intention mahasiswa. Jurnal Ekonomi Bisnis, 16(2), 126-135.

Segal, G., Borgia, D. \& Schoenfeld, J. (2005). The motivation to become an entrepreneur. International Journal of Entrepreneurial Behavior \& Research, 11(1), 42-57.

Sharma, L. (2018). Entrepreneurial intentions and perceived barriers to entrepreneurship among youth in Uttarakhand state of India. International Journal of Gender and Entrepreneurship, 10(3), 243-269.

Smith, R. M., Sardeshmukh, S. R. \& Combs, G. M. (2016). Understanding gender, creativity, and entrepreneurial intentions. Education + Training, 58(3), 263-282.

Solesvik, M., Westhead, P. \& Matlay, H. (2014). Cultural factors and entrepreneurial intention: The role of entrepreneurship education. Education + Training, 56(8/9).

Solimun, Fernandes, A. A. R. \& Nurjannah. (2017). Metode Statistika Multivariat Pemodelan Persamaan Struktural (SEM) Pendekatan WarpPLS. Malang: Universitas Brawijaya Press.

Srivastava, S. \& Misra, R. (2017). Exploring antecedents of entrepreneurial intentions of young women in India. Journal of Entrepreneurship in Emerging Economies, 9(2), 181-206.

Stedham, Y. \& Wieland, A. (2017). Culture, benevolent and hostile sexism, and entrepreneurial intentions. International Journal of Entrepreneurial Behavior \& Research, 23(4), 673-687. 
Sugiyono. (2017). Metode Penelitian Pendidikan (Pendidikan Kuantitatif, Kualitatif dan R\&D). Bandung: Alfabeta.

Suharti, L. \& Sirine, H. (2011). Faktor-Faktor yang Berpengaruh terhadap Niat Kewirausahaan (Entrepreneurial Intention) (Studi terhadap Mahasiswa Universitas Kristen Satya Wacana, Salatiga). Jurnal Manajemen Dan Kewirausahaan, 13(2), 124-134.

Teixeira, S. J., Casteleiro, C. M. L., Rodrigues, R. G. \& Guerra, M. D. (2018). Entrepreneurial intentions and entrepreneurship in European countries. International Journal of Innovation Science, 10(1), 22-42.

Tipu, S. A. A. \& Ryan, J. C. (2016). Predicting entrepreneurial intentions from work values. Management Decision, 54(3), 610-629.

Tong, X. F., Tong, D. Y. K. \& Loy, L. C. (2011). Factors influencing entrepreneurial intention among university students. International Journal of Social Sciences and Humanity Studies, 3(1), 487-496.

Urban, B. \& Kujinga, L. (2017). The institutional environment and social entrepreneurship intentions. International Journal of Entrepreneurial Behavior \& Research, 23(4), 638-655.

Wijaya, T. (2009). Kajian model empiris perilaku berwirausaha UKM DIY dan Jawa Tengah. Jurnal Manajemen Dan Kewirausahaan, 10(2), 93-104. 